\title{
Tumor de Abrikossoff: revisión de la literatura y presentación de tres casos
}

\author{
Abrikossoff's tumor: literature review and report of three cases
}

\author{
R. Luaces Rey', J.L. Crespo Escudero², B. Patiño', J. Ferreras², O. Robles Veiga', J.L. López-Cedrún
}

\begin{abstract}
Resumen: El tumor de células granulares (TCG) es una lesión benigna e infrecuente, que se suele presentar como una masa asintomática de menos de dos centímetros de diámetro. Aunque su origen todavía permanece desconocido, se sospecha que es neural (célula de Schwann), debido a estudios inmunohistoquímicos. Puede aparecer en cualquier parte del cuerpo, pero la región de la cabeza y el cuello es la más habitual (50\%). En la cabeza y cuello, la lengua es la localización más común del TCG, seguida por la piel, la laringe, y los sistemas respiratorio y digestivo.

En el estudio histológico, es característica la presencia de hiperplasia pseudo-epiteliomatosa, y el epitelio superficial está preservado normalmente. El análisis inmunohistoquímico revela reacción positiva a la proteína S-100, enolasa neuronal y proteínas mielínicas como P0 y P2.

Presentamos tres casos de TCG y un resumen breve de la literatura existente. El primer caso fue diagnosticado en una mujer de 36 años de edad, el segundo en un hombre de 45 años, y el tercero en otro hombre de 55 años. Las lesiones estaban localizadas en el borde lateral, la superficie ventral y la superficie dorsal de la lengua. El tratamiento fue quirúrgico en los tres casos y no hay evidencia de recurrencia del tumor después de un período de seguimiento que varía desde los 8 meses a los 2 años.
\end{abstract}

Palabras clave: Tumor de células granulares; Tumor de Abrikossoff; Mioblastoma de células granulares.

Recibido: 06.01 .07

Aceptado: 23.03 .07

1 Médico Residente. Servicio de Cirugía Oral y Maxilofacial.

2 Médico Adjunto. Servicio de Cirugía Oral y Maxilofacial.

3 Médico Residente. Servicio de Anatomía Patológica.

4 Jefe de Servicio. Servicio de Cirugía Oral y Maxilofacial.

Hospital Juan Canalejo. A Coruña. España

\section{Correspondencia:}

Ramón Luaces Rey

Servicio de Cirugía Oral y Maxilofacial

Hospital Juan Canalejo

Xubias de Arriba 84

A Coruña. España

Email: rluarey@canalejo.org

\begin{abstract}
Granular cell tumor (GCT) is an uncommon bening lession, pressentig as an asympmtomatic mass, less than two centimeters in diameter. The origin is still unknown, althougt it's suspected to be neural (Schwann cell), because of immunohistochemical studies. It can appear in any part of the body, but the head and neck region is the most common (50\%). In the head and neck, the tongue is the most usual location for GCT, followed by the skin, larynx, respiratory and digestive system. In the histological study is caracteristic the presence of pseudo-epitheliomatous hyperplasia, and the overlying ephitelium is usually preserved. Immunohistochemical analisis reveals positive reaction to S-100 protein, neuronal enolase, mielinic protein as PO and P2. We present three cases of GCT of the tongue and a brief review of the literature. The first case was found in a 36 year old woman, the second in a 45 year old man and the third one in a 55 year old man. The lesions were placed in the lateral border, the ventral surface and the dorsal surface of the tongue. The treatment was surgycal, and there was no evidence of recurrence after a period from eight months to two years of follow up.
\end{abstract}

Key words: Granular cell tumor; Abrikossoff tumor; Granular cell myoblastoma. 


\section{Introducción}

El tumor de células granulares (TCG) fue descrito por primera vez por Abrikossoff en 1926.' La primera teoría sugirió un origen miogénico, hoy descartado por la presencia del tumor en áreas sin fibras musculares y ausencia de mioglobina en las células granulares. ${ }^{2}$ En los últimos tiempos, se ha empezado a defender el origen neurogénico (células de Schwann) de las células que forman el tumor, basándose principalmente en estudios inmunohistoquímicos.

EI TCG puede presentarse en casi cualquier parte de la anatomía, como la piel, la laringe, el sistema nervioso, tracto gastrointestinal, vejiga urinaria, aparato reproductor femenino o los bronquios. ${ }^{3}$ El lugar de aparición más frecuente es la cabeza y cuello (45\%-65\%), de las cuales el $70 \%$ son lesiones intraorales. ${ }^{4}$ Generalmente, se observan como un nódulo solitario asintomático de tamaño menor de 2 centímetros, que afecta a tejido subcutáneo o submucoso. ${ }^{5}$ El epitelio que lo cubre está habitualmente intacto, ${ }^{6}$ pero cuando la lesión es grande puede tener una superficie ulcerada, lo que puede simular un proceso neoplásico. A pesar de que la malignización es un proceso que se observa muy raras veces, hay estudios sobre la posible transformación maligna de este tipo de lesión benigna y también han sido presentados casos de aparición sincrónica de carcinoma de células escamosas y tumor de células granulares. ${ }^{7}$

La base del diagnóstico es el estudio histológico, debido a su inespecífica apariencia clínica. Es muy frecuente la presencia de hiperplasia pseudo-epitelomatosa del epitelio oral que lo cubre. En el caso de las lesiones que afectan a la lengua, ésta puede ser tan pronunciada que en ocasiones se confunde con carcinoma de células escamosas. Los estudios inmunohistoquímicos apoyan un origen neurogénico o neuroectodérmico de las células granulares. ${ }^{5} \mathrm{El}$ tratamiento se basa en la cirugía, y el porcentaje de recurrencia descrito ha sido muy bajo.

\section{Casos clínicos}

Una mujer de 36 años de edad fue derivada al Servicio de Cirugía Oral y Maxilofacial del Hospital Juan Canalejo por un pequeño nódulo (1,5 cm de diámetro) asintomático de 3 meses de evolución, localizado en el borde lateral derecho de la lengua (Fig. 1). Se le había realizado previamente una biopsia en otro hospital, con el resultado de mioblastoma de células granulares. No se palpaban adenopatías cervicales y la mucosa que lo recubría era de color blanco amarillento. Bajo anestesia general se procedió a la extirpación del nódulo lingual (Figs. 2 y 3). Los cortes teñidos con hematoxilina-eosina mostraron una masa de bordes mal definidos, con células de núcleo pequeño con numerosos gránulos y algún nucléolo prominente. La actividad mitótica era baja y no se observaban atipias celulares. El diagnóstico definitivo fue de mioblastoma de célu-

\section{Introduction}

Abrikossoff described granular cell tumor (GCT) for the first time in 1926.' The original hypothesis attributed a myogenic origin to the tumor, but that has now been ruled out due to the presence of the tumor in areas without muscular fibers and the absence of myoglobin in granular cells. ${ }^{2}$ The neurogenic origin of the cells forming the tumor (Schwann cells) has been defended in recent years, based on immunohistochemical studies.

GCT may occur in almost any part of the body, such as the skin, larynx, nervous system, gastrointestinal tract, urinary bladder, feminine reproductive system, or bronchi. ${ }^{3}$ The most frequent area of occurrence is the head and neck (45-65\%), where $70 \%$ of lesions are intraoral. ${ }^{4}$ Generally, an asymptomatic solitary nodule of less than 2 centimeters that affects subcutaneous or submucosal tissue is observed. The epithelium covering the tumor is usually intact, ${ }^{6}$ but it may be ulcerated over large lesions, which can simulate a malignant neoplastic process. Although rare, the possible malignant transformation of this type of benign lesion has been studied. Cases of synchronous occurrence of squamous cell carcinoma and granular cell tumor have been reported. 7

Diagnosis is based on histologic study because of the non-specific clinical appearance of the tumor. Pseudo-epitheliomatous hyperplasia of the oral epithelium covering the tumor is frequently present. In lesions affecting the tongue, hyperplasia may be so pronounced that it can be confused with squamous cell carcinoma. Immunohistochemical studies support the neurogenic or neuroectodermic origin of the granular cells.5 Treatment is surgical and the recurrence rate is very low.

\section{Clinical cases}

A 36 year old woman was referred to the Oral and Maxillofacial Surgery Department of Hospital Juan Canalejo for a small, asymptomatic nodule ( $1.5 \mathrm{~cm}$ diameter) of 3 months of evolution, located on the right side of the tongue (Fig. 1). A previous biopsy from another hospital reported granular cell myoblastoma. No cervical lymph nodes were palpated and yellowish white mucosa covered the tumor. The lingual nodule was excised under general anesthesia (Figs. 2 and 3). Hematoxylin-eosin stained sections revealed a mass with poorly defined margins containing cells with small nuclei, numerous granules, and some prominent nucleoli. Cellular 
las granulares, y el paciente está libre de enfermedad dos años después de la intervención quirúrgica.

El segundo paciente es un hombre de 40 años de edad, que acudió a nuestra consulta por una formación papilomatosa de $2 \mathrm{~cm}$ de diámetro en la superficie lingual ventral de 4 meses de evolución (Fig. 4). Se trataba de una lesión asintomática cubierta por mucosa de aspecto normal. No se apreciaron alteraciones en el resto de la exploración. Se practicó una biopsia excisional bajo anestesia general y el diagnóstico histológico fue de mioblastoma de células granulares (Figs. 5, 6 y 7).Un año y medio tras la cirugía no hay recidiva de la enfermedad.

El tercer caso es el de un hombre de 55 años, que consultaba por una tumoración no dolorosa en la superficie lingual dorsal. La exploración mostró una pequeña masa nodular de $1 \mathrm{~cm}$ de diámetro, con mucosa normal. No había alteraciones en el resto de la exploración extraoral. Bajo anestesia local se realizó una biopsia-extirpación y el diagnóstico histológico fue de mioblastoma de células granulares lingual. El paciente está libre de enfermedad ocho meses tras la cirugía.

\section{Discusión}

El origen del tumor de células granulares (TCG) es aún controvertido. ${ }^{8}$ Han sido sugeridos varios posibles orígenes como músculo esquelético, macrófagos, células mesenquimales indiferenciadas y pericitos. Pero estas teorías han sido descritas de manera incompleta. ${ }^{9}$ Basándose en estudios inmunohistoquímicos, el origen neural es el más aceptado hoy en día.

Pueden verse afectados pacientes de cualquier edad, pero es más habitual en las edades comprendidas entre los 20 y los 50 años, y es más frecuente en mujeres. ${ }^{10}$ Esta lesión suele aparecer como un pequeño nódulo solitario (menor de $2 \mathrm{~cm}$ ) bien definido, no inflamado y asintomático. El TCG suele ser una lesión con la superficie no ulcerada, y la mucosa que lo cubre tiene color blanco, amarillento, rojizo, azulado o grisáceo. ${ }^{10}$ Ocasionalmente han sido descritos casos con múltiples lesiones.

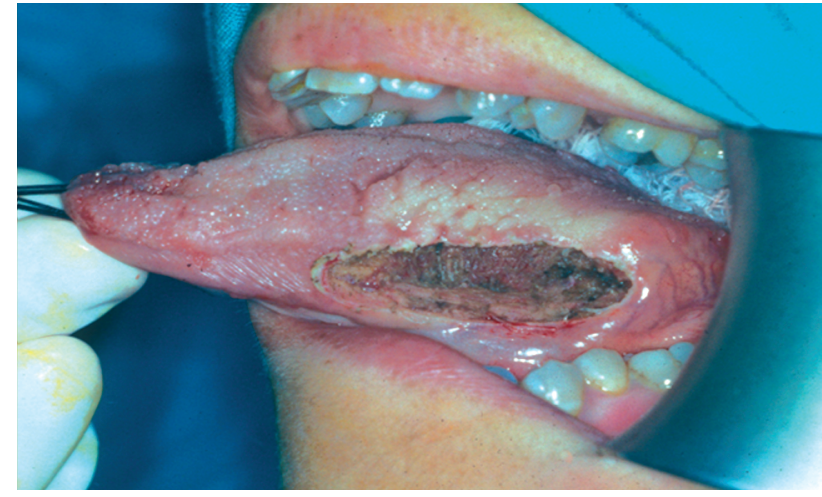

Figura 2. Caso 1. Cirugía: "Resección quirúrgica amplia debido a márgenes mal definidos".

Figure 2. Case 1. Surgery: surgical resection enlarged due to poorly defined margins.

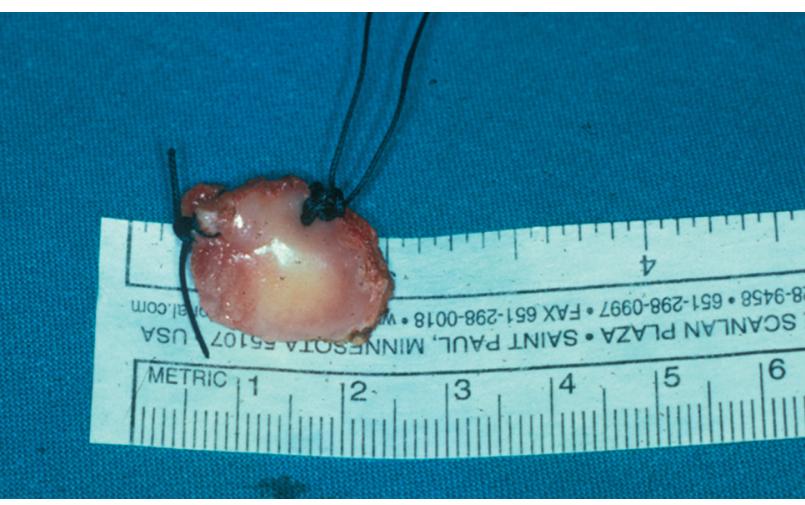

Figura 3. Caso 1. Tumor: "Tumor submucoso no encapsulado". Figure 3. Case 1. Tumor: unencapsulated submucosal tumor.

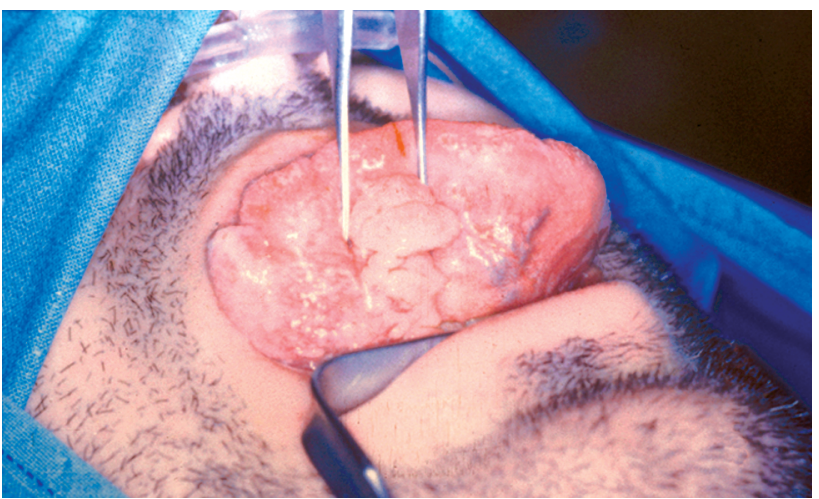

Figura 4. Caso 2. Antes de la cirugía: "Tumor de Células Granulares de la superficie ventral lingual".

Figure 4. Case 2. Before surgery: granular cell tumor of the ventral tongue surface. mitotic activity was low and no atypia was observed. The definitive diagnosis was granular cell myoblastoma and the patient was diseasefree two years after surgery. The second patient was a 40-year-old man seen for a papillomatous formation, 2 $\mathrm{cm}$ in diameter, on the ventral surface of the tongue of 4 months evolution (Fig. 4). The asymptomatic lesion was covered by mucosa of normal appearance. The rest of the examination disclosed no abnormalities. An excisional biopsy was performed under general anesthesia and the histologic diagnosis was granular cell myoblastoma (Figs. 5, 6 and 7). One year and a half after surgery there was no recurrence of the disease.

The third case was a 55 year-old man who consulted for a painless tumor on the dorsal tongue surface. The examination disclosed a small nodular mass $1 \mathrm{~cm}$ in diameter with a normal mucosa. No abnormalities were found in the extraoral examination. An excisional biopsy was performed under local anesthesia and the histologic diagnosis was granular cell myoblastoma of the tongue. The patient remained disease-free eight months after surgery.

\section{Discussion}

The origin of granular cell tumor (GCT) is still controversial. ${ }^{8}$ Several possible origins have been suggested, e.g., skeletal muscle, macrophages, undifferentiated mesenchymal cells, and pericytes. However, these theories were never been fully substantiated. ${ }^{9}$ A neural origin is now accepted based on immunohistochemical studies. 
El TCG puede aparecer tanto en piel como en tejido subcutáneo, y en algunas ocasiones puede ser identificado en pulmón, tracto gastrointestinal, tejido cardíaco, ${ }^{9}$ sistema nervioso, vejiga urinaria, aparato reproductor femenino o glándula parótida. ${ }^{5}$ En un $4 \%$ al $65 \%$ de los casos la región de la cabeza y cuello se ve afectada, en la que la lengua es con gran diferencia la localización más habitual. Han sido descritos casos localizados en la mucosa bucal, paladar duro, labio, encía o úvula.

El diagnóstico diferencial incluye lesiones vasculares de la lengua, adenoma pleomorfo, quiste dermoide, lipoma, fibroma traumático, ${ }^{5}$ leiomioma, schwanoma, neurofibroma, rabdomioma ${ }^{6}{ }^{6}$ infoma y en niños una lesión conocida con el nombre de tumor congénito gingival de células granulares (épulis congénito). ${ }^{9}$

Los hallazgos histológicos nos dan el diagnóstico definitivo. El epitelio que lo cubre está normalmente intacto, pero es frecuente la presencia de hiperplasia pseudo-epitelomatosa. Este puede ser un hecho tan marcado que una biopsia superficial de una lesión así podría ser diagnosticada como carcinoma bien diferenciado de células escamosas. El tumor de células granulares posee células redondeadas o poligonales con pequeños núcleos y abundante citoplasma granulado eosinofílico pálido. ${ }^{8}$ Histoquímicamente, los gránulos citoplasmáticos son PAS positivos y diastasa resistentes..$^{10} \mathrm{El}$ núcleo está en posición excéntrica y las figuras mitóticas son raras.

El TCG es una lesión no encapsulada subcutánea o submucosa y en ocasiones el tumor parece infiltrar el tejido conectivo adyacente. En algunos casos, las células están en íntima relación con las fibras de músculo estriado, y da la impresión de que proviene de éstas. Sin embargo, pueden tener incluso una disposición perineuronal y perivascular. ${ }^{10}$ El origen neurogénico se apoya en la localización inmunohistoquímica de marcadores de la enolasa neuronal específica y de la proteína S-100 en las células tumorales. ${ }^{8}$

Aunque en raras ocasiones de ve transformación maligna, ${ }^{5}$ ésta ha sido

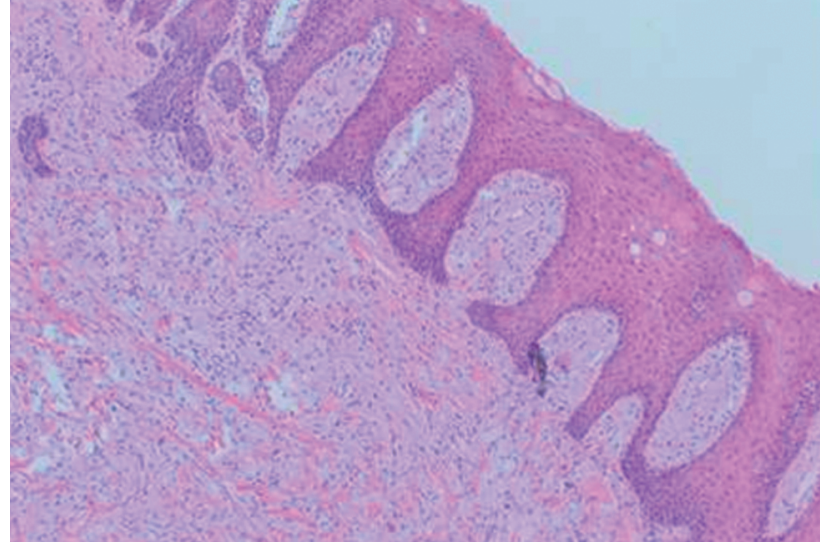

Figura 5. Caso 2. Hematoxilina-eosina 4x: "Bajo grado de mitosis, sin áreas de necrosis y sin atipias celulares".

Figure 5. Case 2. Hematoxylin-eosin 4x: low-grade mitosis with no areas of necrosis or cellular atypia.

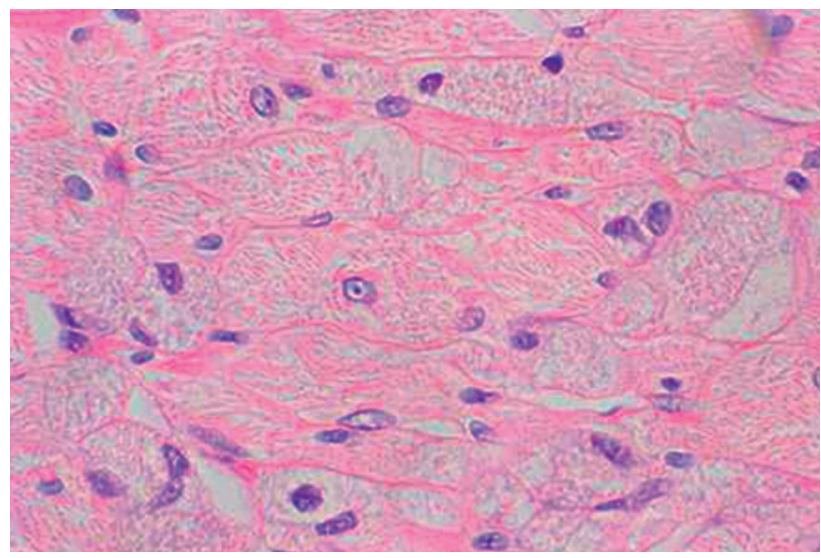

Figura 6. Caso 2. Hematoxilina-eosina 40x: "Células con citoplasma pálido lleno de numerosos gránulos".

Figure 6. Case 2. Hematoxylin-eosin 40x: cells with pale cytoplasm containing numerous granules.

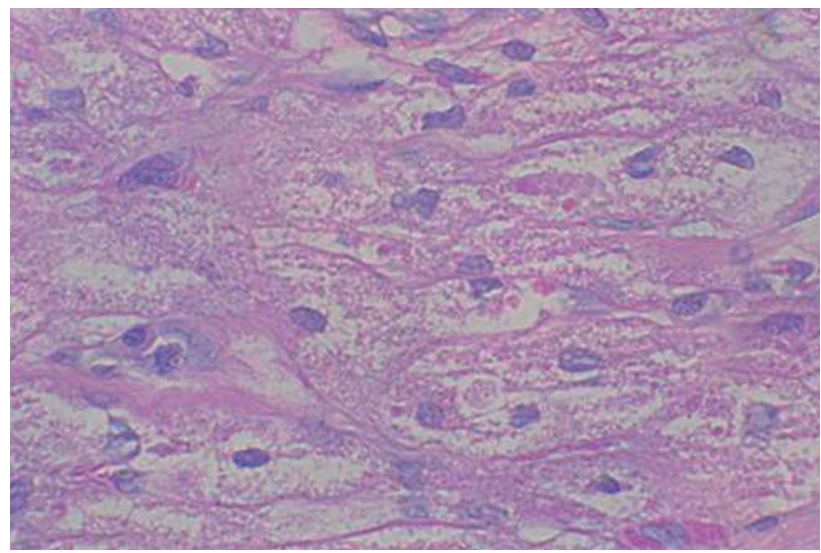

Figura 7. Caso 2. PAS 40x: "Histoquímicamente los gránulos citoplasmáticos son PAS-positivos".

Figure 7. Case 2. PAS 40x: cytoplasmic granules are PAS-positive histochemically.
Patients of any age may be affected, but CGT is more common in patients age 20 to 50 years and in women. ${ }^{10}$ This lesion usually presents as a small, well-defined solitary nodule (less than $2 \mathrm{~cm}$ ) with no inflammation or symptoms. GCT usually does not originate surface ulceration and the mucosa covering is white, yellowish, reddish, bluish, or grayish in color. ${ }^{10}$ Cases with multiple lesions have been described occasionally.

GCT may appear in skin and subcutaneous tissue. It is identified sometimes in lung, gastrointestinal tract, heart, 9 nervous system, urinary bladder, feminine reproductive system, or parotid gland. ${ }^{5}$ The head and neck region is affected in 4 to $65 \%$ of cases, the tongue being by far the most common location. Cases of tumors in the buccal mucosa, hard palate, lip, gum, and uvula have been reported.

The differential diagnosis includes vascular lesions of the tongue, pleomorphic adenoma, dermoid cyst, lipoma, traumatic fibroma, ${ }^{5}$ leiomyoma, schwannoma, neurofibroma, rhabdomyoma, ${ }^{6}$ lymphoma and, in children, a well-known lesion with the name of congenital gingival granular cell tumor (congenital epulis). ${ }^{9}$

Histologic findings yield the definitive diagnosis. The epithelium covering a GCT is normally intact, but pseudo-epithelomatous hyperplasia is often present. The hyperplasia may be so marked that the surface biopsy of such a lesion could 
descrita. ${ }^{2}$ Alrededor del 2\% de los tumores de células granulares sufren malignización, y también han sido presentados casos de aparición sincrónica con carcinoma de células escamosas. ${ }^{7}$

La Punción Aspiración con Aguja Fina (PAAF) y técnicas de imagen como la Tomografía Computerizada, Resonancia Magnética o ultrasonografía pueden ser útiles en el diagnóstico de este tumor benigno. 5 Pero el diagnóstico definitivo nos lo da el análisis histológico.

El tratamiento más aceptado es la escisión quirúrgica de la lesión. Como el TCG tiene unos márgenes mal definidos, se sugiere que la resección debe practicarse incluyendo una porción de tejido sano adyacente. 2,5 Este tumor por norma general tiene un comportamiento clínico benigno, y las recurrencias son infrecuentes. ${ }^{6}$ Se recomienda un seguimiento a largo plazo para evitar posibles recurrencias y malignización. 5

\section{Bibliografía}

1. Abrikossoff Al. Uuber myome ausgehend von der quergestreifeten willkurlichen muskulatur. Virchows Arch (Pathol Anat) 1926;260:215-33.

2. Rivas Lacarte MP, Perello Schrdel E, Gonzalez J, Novel V. Abrikossoff's tumor. Ann Otorrinolaringol Ibero Am 1996;23:425-30.

3. Enzinger FM, Weiss SW. Soft Tissue Tumors. 2nd ed. St Louis. MO: CV Mosby; 1988;p.p. 757-65.

4. Noonan JD, Horton CE, Old WE, Lane T. Granular cell myoblastoma of the head and neck. Review of the literature and 10 years of experience. Am / Surg 1979; 138:611.

5. Nagaraj PB, Ongole R, Bhujanga-Rao BR. Granular cell tumor of the tongue in a 6-year-old girl a case report. Med Oral Patol Oral Cir Bucal 2006;11: E162-4.

6. Calvo Boizas E, Diego Perz Cl, Sancipriano Hernández JA, Hermosa Finamor P, Ahmad IS, Gómez Toranzo F. Granular cell tumor. A lingual case report. An Otolaryngol Ibero Am 2001;28:621-9.

7. Said-al-Naief N, Brandwein M, Lawson W y cols. Synchronous lingual granular cell tumor and squamous carcinoma: case report and review of the literature. Arch Otolaryngol Head Neck Sur 1997;123:543-7.

8. Sapp JP, Eversole LR, Wysocki GP. Patología Oral y Maxilofacial Contemporanea. 2nd ed. Ed Mosby 2005; 309-11.

9. Kyrmikazis DE, Nicolidakis AA, Panayiotides JG, Christodoulu P, Helidonis E. Lingual granular cell tumor. Otolaryngol Head Nek Surg 2001;125:422-3.

10. Zangari F, Trombelli L, Calura G. Granular cell myoblastoma. Review of the literature and report of a case. Minerva Stomatol 1996;45:231-7. be diagnosed as well differentiated squamous cell carcinoma. Granular cell tumors contain round or polygonal cells with small nuclei and abundant eosinophilic granulated pale cytoplasm. ${ }^{8}$ Histochemically, the cytoplasmic granules are PAS-positive and diastase-resistant. ${ }^{10}$ The nucleus is eccentric and mitotic figures are rare.

GCT is a subcutaneous or submucosal unencapsulated lesion that sometimes infiltrates the adjacent connective tissue. In some cases, the cells are intimately related with striate muscle fibers, suggesting that they arise from this tissue. However, they may also have a perineuronal and even perivascular disposition. ${ }^{10}$ The neurogenic origin is supported by the identification in tumor cells of specific neuronal enolase and protein S-100 immunohistochemical markers. ${ }^{8}$

Malignant transformation has been observed on rare occasions ${ }^{5}$ and it has been described. ${ }^{2}$ Around $2 \%$ of granular cell tumors undergo malignant transformation and cases of synchronous occurrence with squamous cell carcinoma have been reported. ${ }^{7}$

Fine needle aspiration biopsy (FNAB) and imaging techniques like computed tomography, magnetic resonance, and ultrasonography can be useful in the diagnosis of this benign tumor. ${ }^{5}$ However, the definitive diagnosis is histologic.

The most widely accepted treatment is surgical excision of the lesion. GCT has poorly defined margins so the resection should include margins of adjacent healthy tissue. ${ }^{2,5}$ The clinical behavior of the tumor is generally benign and recurrence is infrequent. ${ }^{6}$ Long-term follow-up is recommended to detect possible recurrences and malignant transformation. ${ }^{5}$ 